\title{
Quality Assessment of Waterside River, Ogbor Hill Aba 4: Effect of Three-Point Samples on Hepatic Histo-Morphology and Some Seric Bio-Functional Indicators of Wistar Rats
}

\author{
Anthony Cemaluk C. Egbuonu ${ }^{1}$, Okechukwu C. Atasie ${ }^{1,2^{*}}$ Chimaroke Onyeabo, \\ Nancy O. Uchenna ${ }^{1}$ \\ ${ }^{I}$ Department of Biochemistry, College of Natural Sciences, Michael Okpara University of Agriculture Umudike, \\ Nigeria \\ ${ }^{2}$ Department of Biochemistry, Abia State University, Uturu, Nigeria
}

*Corresponding Author: Okechukwu C. Atasie, Department of Biochemistry, College of Natural Sciences, Michael Okpara University of Agriculture Umudike, Nigeria

\begin{abstract}
Three-point samples from waterside River Ogbor hill Aba (WRO) were assessed for heavy metals content and effect on rats' hepatic histo-morphology and seric bio-indicators using standard protocols. Heavy metals were least in upstream compared to downstream and midstream samples. Upstream exposure lowered $(p<0.05)$ while midstream and downstream exposure increased $(p<0.05)$ serum alanine aminotransferase $(A L T)$ activity as compared to control rats. The higher $(p<0.05)$ serum aspartate aminotransferease (AST) activity of the samples compared to control was statistically different $(p<0.05)$ among the groups. Serum alkaline phosphatase (ALP) activity in the three-point samples-treated rats was statistically higher $(p<0.05)$ compared to control but comparatively lower $(p<0.05)$ in the upstream-exposed rats. Higher $(p<0.05)$ computed AST:ALT (lower ALT:AST) and lower $(p<0.05)$ ALT:ALP (higher ALP:ALT) ratios in the upstream-exposed rats compared to the other groups, but statistically higher $(p<0.05)$ ALP:AST (lower ALP:AST) ratios in the samples-exposed rats compared to control excluded liver damage from upstream-induced effects while implicating other high metabolic organs damage with the three-point samples-induced effects. Moderately deranged hepatic histomorphology of upstream-exposed rats but widespread hydropic degeneration or completely congested portal vein of either midstream or downstreamexposed rats' histo-morphology suggested milder upstream-induced hepatic histo-morphologic derangement while confirming the seric results. The study demonstrated high heavy metals and attendant nom-potability in, notably midstream and downstream, samples from WRO that seemingly reflected the adversity on the hepatic histomorphology and seric bio-indicators of the rats, warranting urgent intervention and further studies that could ensure the obliteration of the heavy metal content of waterside river Ogbor hill, Aba.
\end{abstract}

Keywords: Diagnostic ratios, Histo-morphology, Alkaline phosphatase, Alanine aminotransferase, Aspartate aminotransferase

\section{INTRODUCTION}

Water quality is critical to overall animal physiology ${ }^{[1]}$. And, to a large extent, it depends on the water source, prevailing environmental factors and human activities ${ }^{[2,3]}$. Water pollution resulting from environmental factors as well as human and industrial activities could be worsened with poor urban sewage system and consequent seepage of wastes to streams ${ }^{[4]}$ along with heavy metals can enter streams. Heavy metals are not biodegradable hence could bioaccumulate to exert varied toxic influences in animals, aside compromising the water quality or potability ${ }^{[5-10]}$. Thus, the seepage of heavy metals into streams is a significant environmental problem hence worrisome ${ }^{[11,12]}$. Either banks of waterside River Ogbor hill Aba traverse the rear of many factories, including breweries, soaps and detergents factories. This coupled with activities peculiar to abattoirs (hide and skin burning), auto mechanic workshops, human wastes, and general refuse disposal by the teaming inhabitants in the densely populated waterside area could predispose WRO to contamination and pollution. Earlier reports indicated acidic property of the WRO samples and attendant adverse influences on indicators of hematological and kidney functions ${ }^{[13,14]}$. 
Liver is the main metabolic organ for detoxification ${ }^{[6]}$. This predisposes the liver to first line damage and degeneration following toxic assault. Hence, assessing liver function remains vital to monitoring adverse influence or otherwise of xenobiotics. Thus, this study aimed to determine some heavy metals compositions of three-point samples of waterside River Ogbor hill Aba (WRO) and to assess the effect of the water samples on hepatic histo-morphology and some seric bio-functional indicators of Wistar rats. The objectives of the study for achieving the study aim as entitled and stated include the determination of cadmium, manganese, iron, zinc, lead, nickel and chromium compositions of threepoint samples from waterside River Ogbor hill Aba as well as assessing the influence of the samples on hepatic histomorphology and serum activity of alanine aminotransferase, aspartate aminotransferase and alkaline phosphatase (and the corresponding diagnostic ratios) of rats. Enzyme activity is particularly important in assessing pathological conditions ${ }^{[15]}$. And, serum alanine aminotransferase and aspartate aminotransferase activities are particularly most used biochemical indicators of hepatocellular injury ${ }^{[16]}$. The results of this study could provide further insight into the quality status of, and possible hepatic health implications of consuming, WRO.

\section{MATERIALS AND METHODS}

\section{Sample collection}

Three-point water samples were collected from the waterside River Ogbor hill Aba thus: The first point, Upstream, the second point, Downstream and the third point, Midstream. The water samples were collected using a properly labeled plastic containers and used without any treatment.

\section{Animal study}

\section{Animal procurement and exposure groups}

Twenty adult male albino rats (Rattus novergicus) used in this study were procured from the animal house of the Faculty of Biological Sciences, University of Nigeria, Nsukka. The animals were acclimatized for 2 weeks and then randomized (based on weight) to four experimentation groups with sample size of five rats.

Rats in the Group A (Control) were sham-exposed to $0.5 \mathrm{ml}$ of clean sachet water while rats in Groups B, C and D were respectively exposed to $0.5 \mathrm{ml}$ of WRO sample collected Upstream, Midstream and Downstream. The exposure was per oral, using a gavage, and daily for 4 weeks (twenty-eight days). Rats in all the groups were allowed free access to water and rat chow (commercial growers mesh feeds (Vital Feeds, Jos Nigeria).

\section{Sacrifice, blood sample collection and preparation}

After 4 weeks (28 days) exposure, the rats were fasted overnight and sacrificed the next day by cardiac puncture technique after cervical dislocation and the blood sample of the respective rats was collected individually into clean non-heparin tubes. The respective blood sample thus collected was allowed to clot and then centrifuged at $3000 \mathrm{~g}$ for $10 \mathrm{~min}$. The resultant serum sample was separated and stored in a refrigerator at $0{ }^{\circ} \mathrm{C}$ and used the next day to determine the studied serum bio-indicators of hepatic functions viz: aspartate amino transferase, alanine amino transferase, alkaline phosphatase activities. Relevant corresponding ratios of these bio-indicators were calculated from the results obtained in this study.

\section{Ethical consideration}

This study considered and adhered to the standard ethical use of experimental animals. Throughout the experimentation (acclimatization and exposure periods), all rats were housed at $25^{\circ} \mathrm{C}$ in stainless steel cages under normal daylight/dark cycle and humid tropical conditions. The rats were allowed free access to rat feed (Vital Feeds, Jos Nigeria) and tap water, and generally received humane care in accordance with the guidelines of the National institute of Health, USA for ethical treatment of laboratory animals as approved by the various (departmental and college) ethical committees of Michael Okpara University of Agriculture Umudike, Nigeria.

Determination of some water quality indicators (some heavy metals viz cadmium, zinc, iron, manganese, nickel, lead, chromium) of WRO samples

Some heavy metals (cadmium, zinc, iron, manganese, nickel, lead, and chromium) in the water samples were determined by the Perchloric acid digestion method as described in ${ }^{[17]}$. The water 
sample was mixed thoroughly before transferring $200 \mathrm{~mL}$ into a flask. A volume of $50 \mathrm{~mL}$ of concentrated $\mathrm{HNO}_{3}$ and a few toiling chips were added and evaporated on a hot plate to $10 \mathrm{~mL}$. Then $5 \mathrm{ml}$ of concentrated $\mathrm{HNO}_{3}$ and $\mathrm{HCLO}_{3}$ were added after boiling in the flask. The solutions were evaporated on the hot plate until dense white fumes of perchloric acid appeared. It was cooled and diluted to $20 \mathrm{~mL}$ with deionized water and boiled to expel chlorine, cooled again and filtered. The content was transferred to a $250 \mathrm{~mL}$ volumetric flask and the volume made up to volume to $100 \mathrm{~mL}$. The digested sample was used for the determination of the concentration of the heavy metals using Atomic Absorption Spectrophotometer (AAS), (UNICAM 939) using the appropriate cathode lamp and wavelengths for each heavy metals by direct aspiration. Mixed acid digested water was used to zero the instrument. The absorbance was compared to the identically prepared standard curve.

\section{Determination of some seric bio-functional indicators of liver (alanine aminotransferase, aspartate aminotransferase and alkaline phosphatase activity)}

Serum alkaline phosphatase activity in the rats' serum was determined using the commercial diagnostic kit (Randox Enzyme Kit, United Kingdom). This was based on the optimized standard method as described ${ }^{[18]}$. Serum aspartate aminotransferase (AST) activity and alanine aminotransferase (ALT) activity were determined by the method of Reitman and Frankel ${ }^{[19]}$ as earlier described earlier ${ }^{[20,21]}$. This was based on the principle that oxaloacetate or pyruvate respectively reacts with chromogen (2,4-dinitrophenyhydrazine) in an alkaline medium to form coloured hydrazone that is proportional in concentration (as measured from the colour intensity) to the aspartate aminotransferase or alanine aminoteransferase activity.

\section{Calculation of some diagnostic ratios and change relative to control}

Diagnostic ratios were calculated from the result of corresponding parameters as obtained in this study. The calculation of change relative to control was as developed earlier ${ }^{[22]}$ and severally used ${ }^{[21,23-28]}$. Change relative to control was calculated using the relation:

Change relative to $K(\%)=\underline{100 \times(V-K)}$

$K$

where $K$ represented the constant group hence constant value and V represented the variable groups hence variable values. It is important that the arrangement order in bracket be adhered to so as to have the accurate sign for the calculated change. However, for accuracy, ease and to avoid rounding off error, this could be computed as a continuous mathematical operation thus:

Change relative to $K(\%)=(V-\mathrm{K}) \times 100$

$K$

\section{Examination of hepatic histo-morphology}

Liver sections were collected and fixed in $10 \% \mathrm{v} / \mathrm{v}$ phosphate buffered formalin for a minimum of 48 hours. The tissues were subsequently trimmed, dehydrated in 4 grades of alcohol $(70 \%, 80 \%, 90 \%$ and absolute alcohol), cleared in 3 grades of xylene and embedded in molten wax. On solidifying, the blocks were sectioned to $5 \mu \mathrm{m}$ thick with a rotary microtome, floated in water bath and incubated at $60^{\circ} \mathrm{C}$ for 30 minutes. The $5 \mu \mathrm{m}$ thick sectioned tissues were subsequently cleared in 3 grades of xylene and rehydrated in 3 grades of alcohol $(90 \%, 80 \%$ and $70 \%)$. The sections were then stained with Hematoxylin for 15 minutes. Blueing was achieved with ammonium chloride while differentiation was with $1 \%$ acidic alcohol before counterstaining with Eosin. Permanent mounts were made on degreased glass slides using a mountant; DPX. The prepared slides were examined with a Motic ${ }^{\mathrm{TM}}$ compound light microscope using $\times 4, \times 10$ and $\times 40$ objective lenses. The photomicrographs were taken using a Motic ${ }^{\mathrm{TM}} 9.0$ megapixels microscope camera at $\times 400$ magnifications

\section{Statistical analysis}

All numeric data collected were analyzed by one way analysis of variance (ANOVA) using the statistical package for Social Sciences (SPSS version 17; SPSS Inc., Chicago.IL.,USA). Results were presented as means \pm standard deviation (Mean \pm SD) at $95 \%$ significance level $(\mathrm{p}<0.05)$. 
Quality Assessment of Waterside River, Ogbor Hill Aba 4: Effect of Three-Point Samples on Hepatic Histo-Morphology and Some Seric Bio-Functional Indicators of Wistar Rats

\section{RESULTS}

Table1. Heavy metals compositions of three-point (Upstream, Midstream and Downstream) water samples from waterside River, Ogbor hill Aba, Abia State, Nigeria

\begin{tabular}{|l|l|l|l|l|}
\hline Parameters $(\mathbf{m g} / \mathbf{l})$ & EPA Standard ${ }^{\#} \mathbf{~ m g} / \mathbf{l}$ & Upstream & Midstream & Downstream \\
\hline Manganese & $\begin{array}{l}\text { Other purposes }=0.05,0.3 \text { and } 0.1 \\
\text { Drinking water }=0.00005\end{array}$ & - & - & - \\
\hline Iron & $\begin{array}{l}\text { Other purposes }=0.2,2.0 \text { and } 2.0 \\
\text { Drinking water }=0.0002\end{array}$ & - & - & - \\
\hline Zinc & General purposes $=0.05$ & - & - & $0.05 \pm 0.01$ \\
\hline Lead & $\begin{array}{l}\text { Other purposes }=0.02 \\
\text { Drinking water }=0.00001\end{array}$ & $0.05 \pm 0.00$ & $0.05 \pm 0.01$ & $0.08 \pm 0.01$ \\
\hline Cadmium & $\begin{array}{l}\text { Other purposes }=0.1 \\
\text { Drinking water }=0.00005\end{array}$ & - & - & - \\
\hline Nickel & $\begin{array}{l}\text { Other purposes }=0.1 \\
\text { Drinking water }=0.00002\end{array}$ & $0.06 \pm 0.01$ & $0.07 \pm 0.01$ & $0.06 \pm 0.01$ \\
Value presented as mean \pm SD of triplicate determinations. Significant difference at $\mathrm{p}<0.05$. \#EPA[2] & \\
\hline
\end{tabular}

As depicted on Table 1, Manganese, Iron and Cadmium were not detected in any of the samples from WRO. Zinc was detected only in the downstream sample and the value was the same as the recommended standard. Lead composition value was higher in the downstream sample than that which was the same in the upstream and midstream samples but none was lower than the recommended standard. Midstream water sample from WRO had the highest Nickel content compared to that which was the same in upstream and downstream samples. The Nickel content in all the water samples was lower than the recommended standard for other purposes but quite high compared to the standard for drinking water. As shown on Figure 1, the Chromium content was highest in the downstream sample followed by that in midstream while the least was in the upstream sample. The Chromium content in all the water samples was lower than the recommended standard for other purposes but higher than the standard for drinking water.

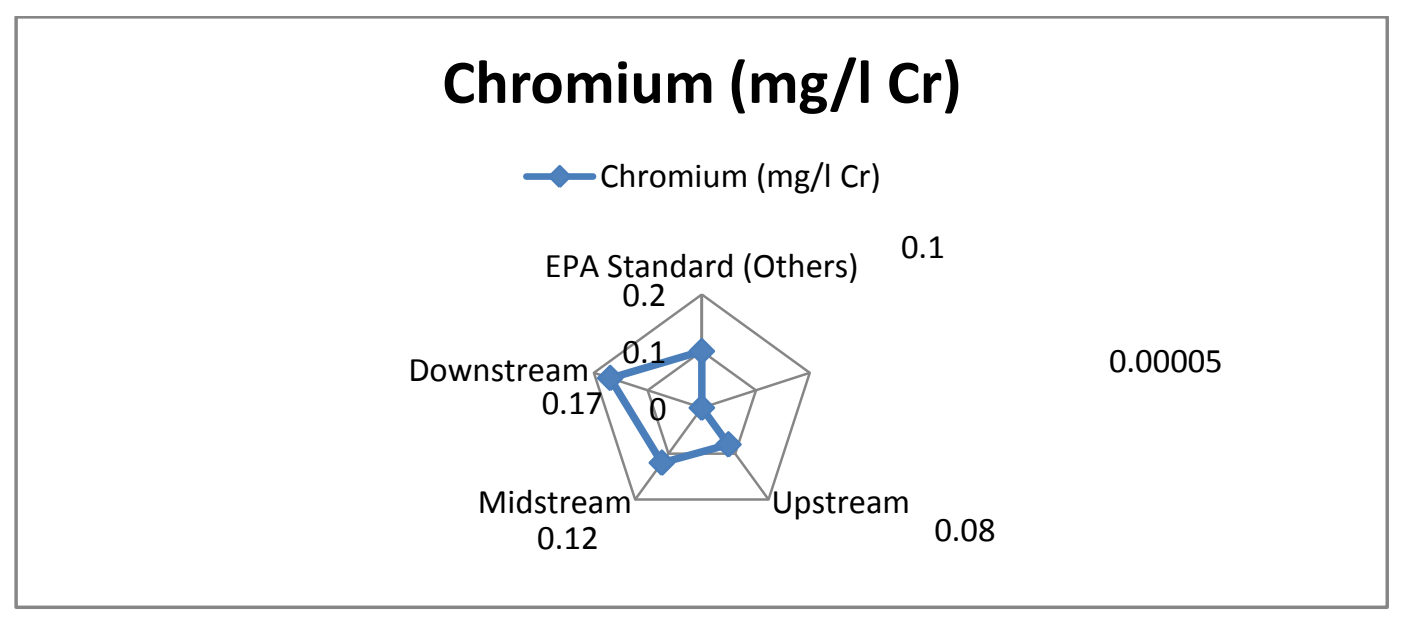

Value presented as mean of triplicate determinations. Significant difference at $\mathrm{p}<0.05$. \#EPA[2]

Figure 1. Standard chromium composition compared with that of three-point (Upstream, Midstream and Downstream) water samples from waterside River, Ogbor hill Aba, Abia State, Nigeria

Table 2. Effect of three-point (Upstream, Midstream and Downstream) water samples from waterside river, Ogbor hill Aba, Abia State on serum ALT activity and AST activity of normal male Wistar rats

\begin{tabular}{|l|l|l|l|l|}
\hline Groups & $\begin{array}{l}\text { ALT } \\
(\mathbf{I U} / \mathbf{L})\end{array}$ & $\begin{array}{l}\text { Change relative to the } \\
\text { Control }(\boldsymbol{\%})\end{array}$ & AST (IU/L) & $\begin{array}{l}\text { Change relative to the } \\
\text { Control }(\%)\end{array}$ \\
\hline Control & $30.40 \pm 2.07$ & 0.00 & $57.40 \pm 2.88$ & 0.00 \\
\hline Upstream & $24.80 \pm 1.92$ & -18.42 & $84.80 \pm 3.83$ & +47.73 \\
\hline Midstream & $60.60 \pm 3.58$ & +99.34 & $114.60 \pm 1.14$ & +99.65 \\
\hline \\
Downstream & $61.00 \pm 2.35$ & +100.65 & $108.00 \pm 1.58$ & +88.15 \\
\hline
\end{tabular}

As depicted on Table 2, the upstream sample from WRO lowered $(\mathrm{p}<0.05)$ the serum ALT activity of the rats by $18.42 \%$ while the midstream and downstream samples increased $(\mathrm{p}<0.05)$ the serum ALT 
Quality Assessment of Waterside River, Ogbor Hill Aba 4: Effect of Three-Point Samples on Hepatic Histo-Morphology and Some Seric Bio-Functional Indicators of Wistar Rats

activity of the rats by 99.34 and $100.65 \%$, respectively as compared with the control. The observed difference in the serum ALT activity of upstream-exposed rats was significant $(\mathrm{p}<0.05)$ compared with that of either midstream or downstream-exposed rats. However, the serum ALT activity of the midstream and downstream-exposed rats was statistically similar ( $>0.05)$. Exposing rats to either upstream, midstream or downstream sample from WRO caused a higher $(\mathrm{p}<0.05)$ serum AST activity compared to the control. The observed serum AST activity was statistically different $(\mathrm{p}<0.05)$ among the respective three-point sample-exposed groups (Table 2).

Table 3. Effect of three-point (Upstream, Midstream and Downstream) water samples from waterside river, Ogbor hill Aba, Abia State on serum ALP activity and AST:ALT (ALT:AST) ratios of normal male Wistar rats

\begin{tabular}{|l|l|l|l|l|}
\hline Groups & $\begin{array}{l}\text { ALP } \\
(\text { IU/L) }\end{array}$ & $\begin{array}{l}\text { Change relative to the } \\
\text { Control }(\%)\end{array}$ & $\begin{array}{l}\text { AST:ALT } \\
\text { (ALT:AST) }\end{array}$ & $\begin{array}{l}\text { Change relative to the } \\
\text { Control }(\%)\end{array}$ \\
\hline Control & $10.64 \pm 0.36$ & 0.00 & $1.89(0.53)$ & $0.00(0.00)$ \\
\hline Upstream & $11.74 \pm 0.26$ & +10.33 & $3.42(0.29)$ & $+80.95(-45.28)$ \\
\hline Midstream & $13.44 \pm 0.38$ & +26.31 & $1.89(0.53)$ & $0.00(0.00)$ \\
\hline Downstream & $13.82 \pm 0.32$ & +29.88 & $1.77(0.56)$ & $-06.35(+5.66)$ \\
\hline
\end{tabular}

As depicted on Table 3, exposing rats to either upstream, midstream or downstream sample from WRO caused statistically higher $(\mathrm{p}<0.05)$ serum ALP activity compared to the control. The observed serum ALP activity of upstream-exposed rats was statistically lower $(p<0.05)$ compared to either that of midstream or downstream-exposed rats which was statistically similar $(\mathrm{p}<0.05)$. The computed AST:ALT ratio in the upstream-exposed rats markedly increased $(\mathrm{p}<0.05)$ above while the ALT:AST ratio decreased $(\mathrm{p}<0.05)$ below the corresponding parameters in the other groups including the control. The computed AST:ALT and ALT:AST ratios of the midstream-exposed rats were similar whereas the reduction in these ratios observed in the downstream-exposed rats was not significant ( $>>0.05$ ) on compared with the control (Table 3 ).

Table 4. Effect of three-point (Upstream, Midstream and Downstream) water samples from waterside river, Ogbor hill Aba, Abia State on serum ALT:ALP (ALP:ALT) and AST:ALP (ALP:AST) ratios of normal male Wistar rats

\begin{tabular}{|l|l|l|l|l|}
\hline Groups & $\begin{array}{l}\text { ALT:ALP } \\
\text { (ALP:ALT) }\end{array}$ & $\begin{array}{l}\text { Change relative to the } \\
\text { Control }(\%)\end{array}$ & $\begin{array}{l}\text { AST:ALP } \\
\text { (ALP:AST) }\end{array}$ & $\begin{array}{l}\text { Change relative to the } \\
\text { Control (\%) }\end{array}$ \\
\hline Control & $2.86(0.35)$ & $0.00(0.00)$ & $5.39(0.18)$ & $0.00(0.00)$ \\
\hline Upstream & $2.11(0.47)$ & $-26.22(+34.28)$ & $7.22(0.14)$ & $33.95(-22.22)$ \\
\hline Midstream & $4.51(0.22)$ & $+57.59(-37.14)$ & $8.53(0.12)$ & $+58.25(-33.33)$ \\
\hline Downstream & $4.41(0.23)$ & $+54.19(-34.28)$ & $7.81(0.13)$ & $+44.89(-27.77)$ \\
\hline
\end{tabular}

The computed ALT:ALP ratio in the upstream-exposed rats decreased $(\mathrm{p}<0.05)$ below while the ALP:ALT ratio increased $(\mathrm{p}<0.05)$ above the corresponding parameters in the other groups including the control. The computed ALT:ALP and ALP:ALT ratios of the midstream-exposed rats were statistically similar $(\mathrm{p}<0.05)$ compared with that of the downstream-exposed rats (Table 4). As depicted on Table 4, exposing rats to either upstream, midstream or downstream sample from WRO caused statistically higher $(\mathrm{p}<0.05)$ computed ALP:AST but lower ALP:AST ratios compared to the control. The observed AST:ALP and ALP:AST ratios were statistically different $(\mathrm{p}<0.05)$ compared among rats exposed to the respective three-point water samples.

\section{Effect of three-point (Upstream, Midstream and Downstream) water samples from waterside river, Ogbor hill Aba, Abia State on the histo-morphology of normal male Wistar rats}

Photomicrograph of liver section collected from animals in the normal group (Plate 1) showed normal hepatic histo-morphology with normal hepatic artery (HA), hepatic vein (HV) and bile duct (B). Photomicrograph of the liver section from rats in the group exposed to upstream water sample showed moderate periportal to midzonal hydropic degeneration as evidenced by normal hepatocytes around the central vein $(\mathrm{V})$ but vacuolated cytoplasm of the hepatocytes further away from the central vein (Plate 2).

Photomicrograph of the liver section of rats that were exposed to the midstream sample from WRO (Plate 3) revealed widespread hydropic degeneration of the hepatocytes within the central vein (V). 
Quality Assessment of Waterside River, Ogbor Hill Aba 4: Effect of Three-Point Samples on Hepatic Histo-Morphology and Some Seric Bio-Functional Indicators of Wistar Rats

Photomicrograph of the liver section of rats in the group that was exposed to downstream sample from WRO (Plate 4) revealed a completely congested portal vein within the central vein (V) and portal area $(\mathrm{P})$.

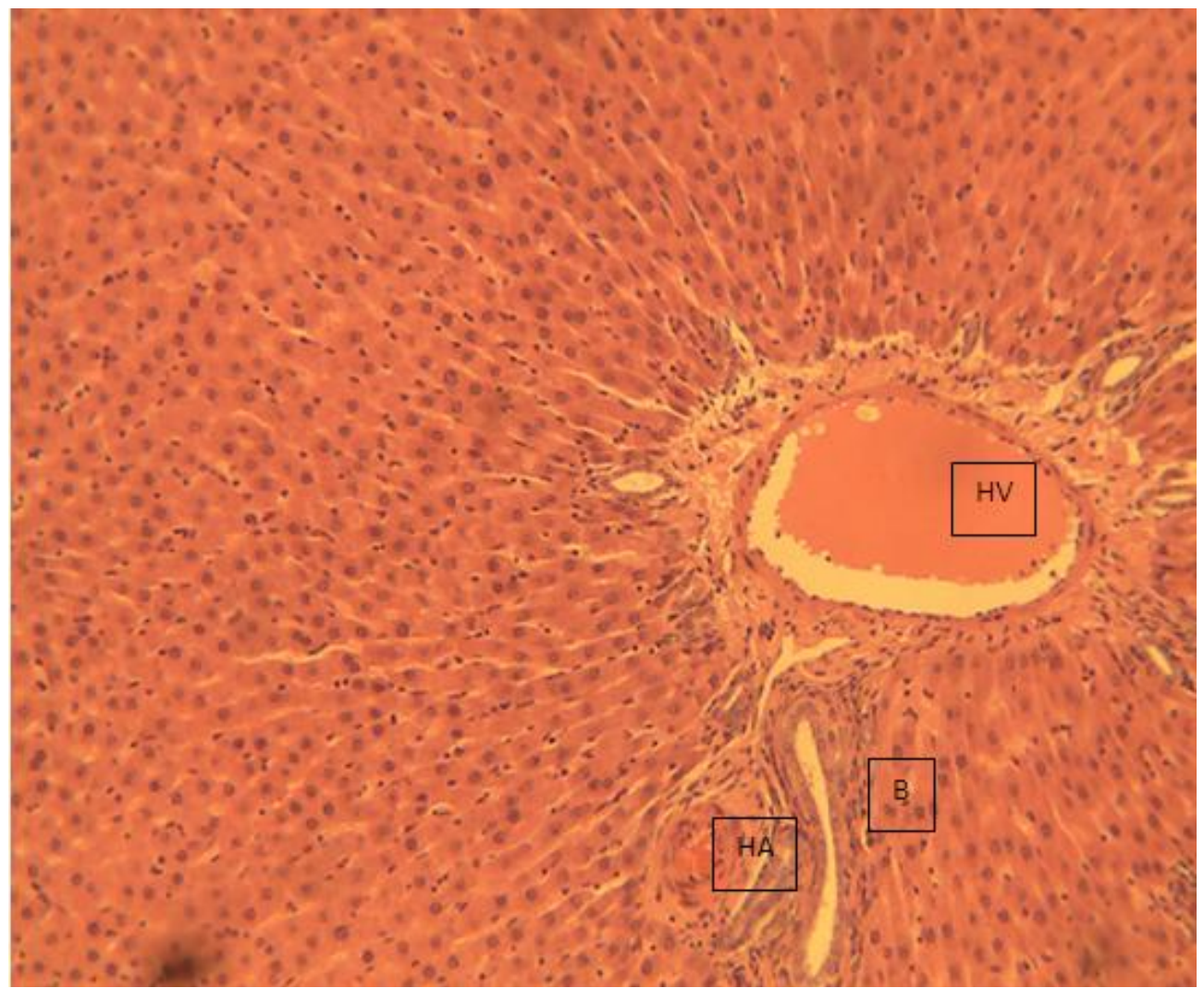

Plate 1. Section of the liver collected from animals in the normalgroup showing the normal hepatic histomorphology. Hepatic artery (HA); hepatic vein $(H V)$; bile ductile (B)

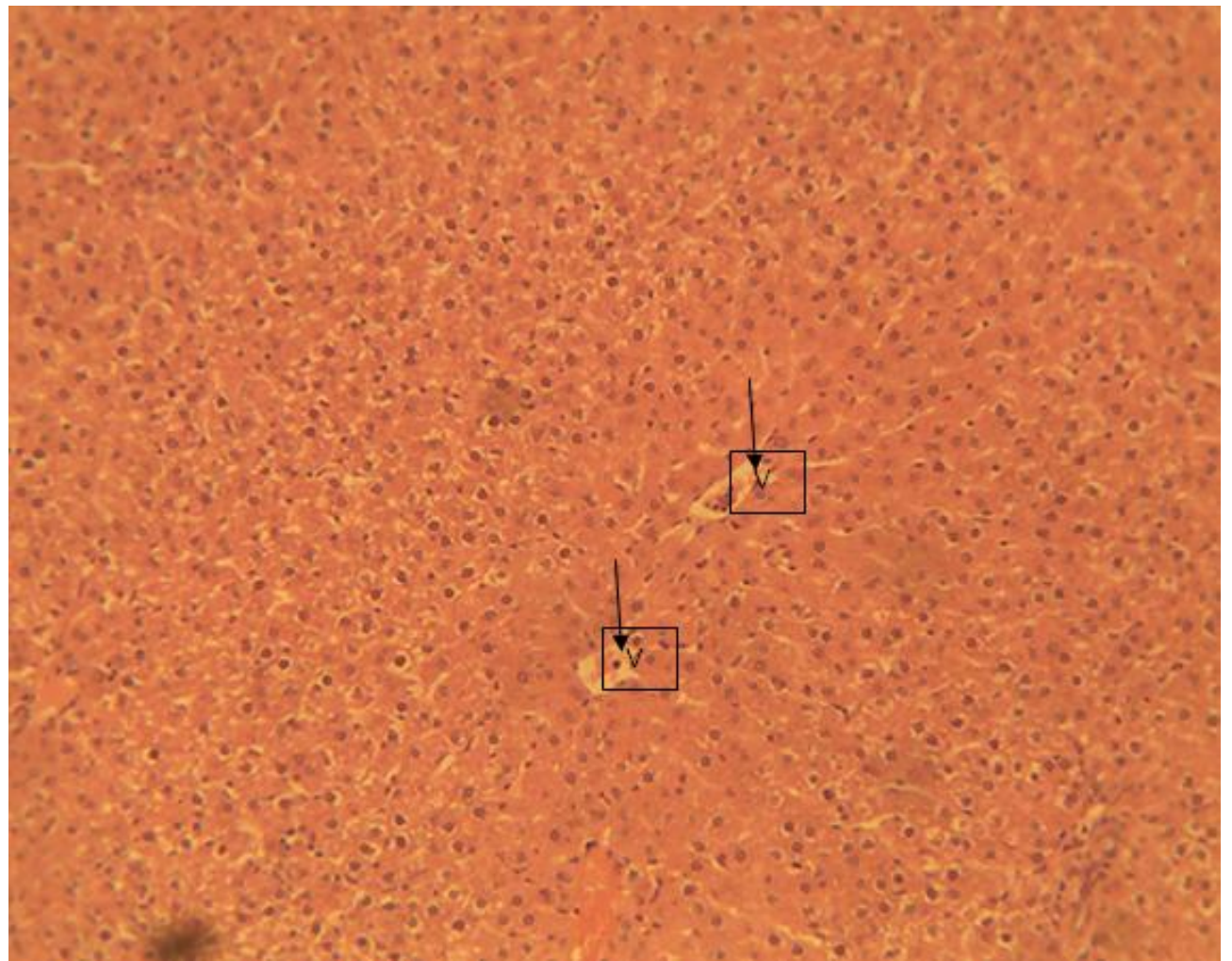

Plate 2. A section of the liver from the group that received upstream water showing moderate periportal to midzonal hydropic degeneration. Notice that the hepatocytes around the central vein (V) are normal while the ones further away from the central vein have vacuoles in the cytoplasm 
Quality Assessment of Waterside River, Ogbor Hill Aba 4: Effect of Three-Point Samples on Hepatic Histo-Morphology and Some Seric Bio-Functional Indicators of Wistar Rats

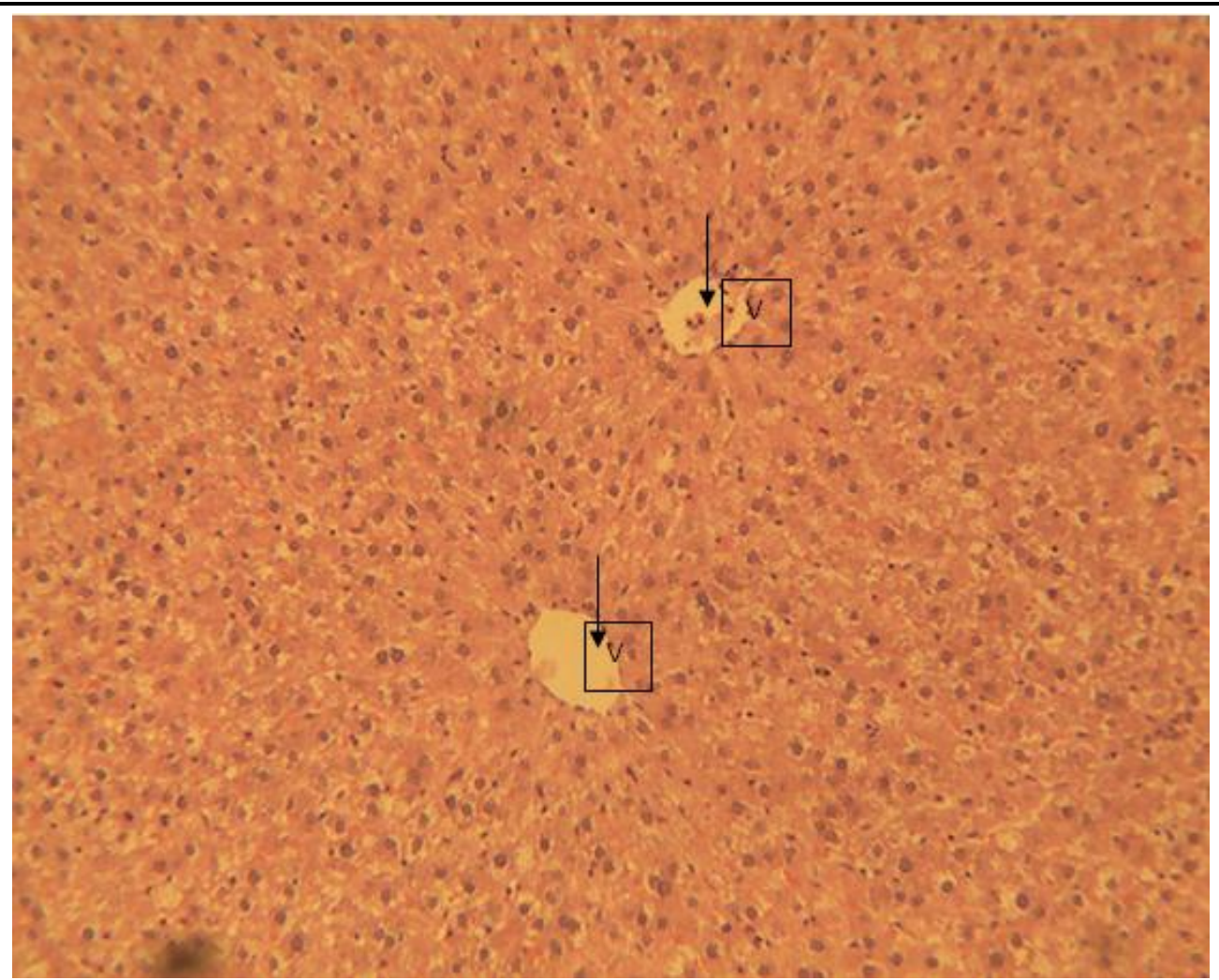

Plate 3. Section of the liver from the group that received midstream water showing widespread hydropic degeneration of the hepatocytes. Central vein $(V)$.

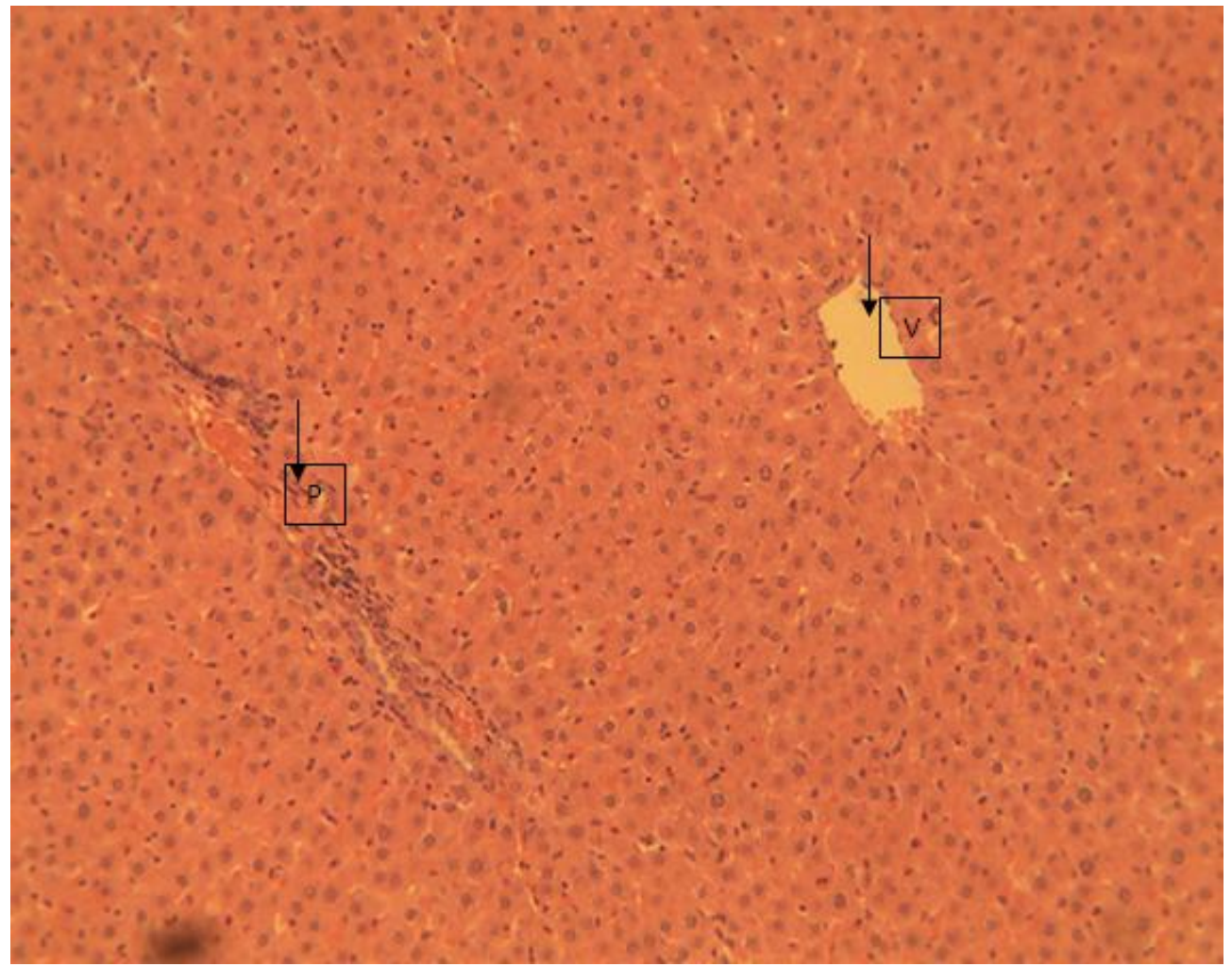

Plate4. Section of the liver collected from animals in the group that received downstream water showing a completely congested portal vein. Central vein $(V)$; Portal area $(P)$

\section{DISCUSSION}

Three-point samples from waterside River Ogbor hill Aba (WRO) were assessed for heavy metals content and effect on rats' hepatic histo-morphology and seric bio-indicators. This was because inhabitants depend solely on WRO notably in the dry season, and water quality is critical to animal 
physiology ${ }^{[3,29]}$. Lead and chromium were, while nickel was, highest respectively in the downstream and midstream samples compared to upstream sample and standard, suggesting possible overriding non-potability ${ }^{[5]}$ and inherent heavy metals-related toxicity of the downstream and midstream samples from WRO. Heavy metals are toxic even at low concentration ${ }^{[30]}$. Thus, the prevalently high content of lead, nickel and chromium as noted in this study may result to toxic manifestation following intake of WRO samples ${ }^{[15]}$.

Change relative to any group was computed in this study as the result has the unique advantage of providing a better understanding of the magnitude of a seemingly negligible numeric change between the compared groups. It thus provides credence to the statistical significance values. In this study, statistical significance $(\mathrm{p}<0.05)$ was confirmed or substantiated by relative change of up to and above ten percent. Upstream sample exposure lowered $(\mathrm{p}<0.05)$ while midstream and downstream samples exposure increased $(\mathrm{p}<0.05)$ serum alanine aminotransferase (ALT) activity as compared to that of control rats. This invariably indicated overriding adverse influence of downstream or midstream samples exposure on the rats' liver since ALT is a specific marker for liver damage ${ }^{[31]}$. In previous studies, increased serum ALT activity indicated liver injury ${ }^{[20,16]}$. Thus, the lower serum ALT activity in the upstream-exposed rats could be suggestive that upstream sample of WRO did not elicit hepatotoxic effect in the rats. The higher $(\mathrm{p}<0.05)$ serum aspartate aminotransferease (AST) activity of the samples compared to control was statistically different $(\mathrm{p}<0.05)$ among the groups. This suggested sample-dependent compromised liver and/or other high metabolic organs in the rats since AST enzyme occurs in other high metabolic organs aside the liver. Serum AST and ALT are the most used biochemical markers of hepatocellular necrosis and are considered sensitive indicators of hepatic injury ${ }^{[16]}$. Heavy metals-induced hepatoxicity have been reported ${ }^{[32]}$ and did result to rise in transaminases in various animals ${ }^{[33,34]}$. The role of liver in detoxification predisposes it to first line damage as could result from heavy metals assault resulting to enhanced release of ALT into the bloodstream as the defense response of the rats against heavy metals ${ }^{[6]}$.

Serum alkaline phosphatase (ALP) activity in the three-point samples-treated rats was statistically higher $(\mathrm{p}<0.05)$ compared to control but lower $(\mathrm{p}<0.05)$ in the upstream-exposed rats compared to midstream and downstream-exposed rats, indicating sample-dependent compromised liver function and/or bone pathologies notably in the midstream and downstream-exposed rats. Lower serum ALP activity indicated lowered possibility of obstructive liver diseases, including cholstasis [20,18], seemingly confirming the possibility that the upstream did not elicit adverse effect on the rats' liver and function. The significant increase in the activity of ALP observed in the downstream and midstream exposed rats may be associated with possible leakage of the enzyme from the liver into the serum that signified hepatic damage ${ }^{[15]}$. Generally, the increase in these enzymes activity (ALT, AST and ALP) may be due to necrosis of the liver and other high metabolic organs that resulted to increased permeability of the organs following toxic assault and resultant damage of the organs ${ }^{[35,36]}$. Heavy metals as noted in the WRO samples in this stud could induce damage on the liver (and other high metabolic organs) resulting to increased cell membrane permeability ${ }^{[16]}$ hence increased release of the enzymes. These alterations could be defense response of the rats against heavy metals ${ }^{[6]}$. Tissue damage related with metals contaminated water have also been documented in other reports ${ }^{[37-39]}$.

Higher $(\mathrm{p}<0.05)$ computed AST:ALT (lower ALT:AST) and lower $(\mathrm{p}<0.05)$ ALT:ALP (higher ALP:ALT) ratios in the upstream-exposed rats compared to that of the other groups, but statistically higher ( $\mathrm{p}<0.05)$ ALP:AST (lower ALP:AST) ratios in the three-point samples-exposed rats compared to control excluded liver damage from upstream-induced effects while implicating other high metabolic organs damage with the respective three-point samples-induced effects. In particular, higher serum AST:ALT ratio greater than the control by one and above indicated cirrhosis (hardening) of major/high metabolic organs in rats ${ }^{[20,21]}$. Thus, the calculated serum ALT:ALP ratio greater than that of the control by one and above could be confirming the implication of damaged liver (and not that of other high metabolic organs) as responsible for the increased ALT activity in the serum while AST:ALP ratio of greater than one compared to the control could be confirmed that increased AST activity resulted from damage to other major organs.

Moderately deranged hepatic histomorphology of upstream-exposed rats but widespread hydropic degeneration or completely congested portal vein of either midstream or downstream-exposed rats' histo-morphology suggested milder upstream-induced hepatic histo-morphologic derangement while 
confirming the seric results. These changes could imply that the significantly high content of some heavy metals (lead, nickel and chromium) in notably the downstream and midstream samples of WRO may have intoxicated the rats liver resulting to the observed histomorphologic changes. Histomorphologic changes confirmed persistent toxic assault on organs in collaboration with seric chemistry results and at times as could not be detected by seric results ${ }^{[16,40-42]}$. The congestion of central vein of the liver as noted in this study was consistent with hepatic response to heavy metals toxic assault in various animal models ${ }^{[6,7,37-39,43,44]}$.

\section{CONCLuSiON}

Thus, the study demonstrated prevalently high heavy metals and attendant non-potability in, notably midstream and downstream, samples from WRO that seemingly reflected the adversity on the hepatic histomorphology and seric bio-indicators of the rats, warranting urgent intervention and further studies that could ensure the obliteration of the heavy metal content of waterside river Ogbor hill, Aba.

\section{REFERENCES}

[1] Okonko IO, Adejoye OD, Ogunnusi TA, Fajobi EA, Shittu OB. Microbial and physicochemical analysis of different water samples used for domestic purposes in Abeokuta and Ojota, Lagos state, Nigeria. Afr. J. Biotechnol. 2008; 7(5):617-621.

[2] Environmental Protection Agency, EPA. Water quality in Ireland 2010-2012. Published by the Environmental Protection Agency, Ireland. 2015; pp. 52-86.

[3] Raji MIO, Ibrahim YKE, Tytler BA, Ehinmidu JO. Physicochemical characteristics of water samples collected from River Sokoto, northwestern Nigeria. Atmospheric and Climate Sci. 2015; (5):194-199.

[4] Mohita K, Birjesh s, Subrata P. Impact of industrial effluents on water quality of Betwa River near Mandideep, Raisen. Int. J. Adv. Res. Biol. Sci. 2017; 4(4): 169-181. doi: http://dx.doi.org/10.22192/ ijarbs.2017.04.04.023 .

[5] Jamali MY, Amir S. Study and evaluation of the physicochemical groundwater quality of an agricultural region around Beni Mellal City. Int. J. Dev. Res. 2017; 07(01):11055-11064.

[6] Javed M, Ahmad I, Usmani N, Ahmad M. Multiple biomarker responses (serum biochemistry, oxidative stress, genotoxicity and histopathology) in Channa punctatus exposed to heavy metal loaded waste water. Scientific Reports. 2017; 7(1675): 1-11. doi:10.1038/s41598-017-01749-6.

[7] Dardouri K, Haouem S, Gharbi I, Sriha B, Haouas Z, El Hani A, Hammami M. Combined effects of Cd and $\mathrm{Hg}$ on liver and kidney histology and function in Wistar rats. J. Agri. Chem. and Environ. 2016; 5:159169. http://dx.doi.org/10.4236/jacen.2016.54017.

[8] Akpor OB, Ohiobor GO, Olaolu TD. Heavy metal pollutants in wastewater effluents: sources, effects and remediation. Adv. Biosci. Bioeng. 2014; 2:37-43. doi:10.11648/j.abb.20140204.11.

[9] SiaSu GL, Gliceria BR, SiaSu MLL. Bioaccumulation and histopathological alteration of total lead in selected fishes from Manila Bay, Philippines. Saudi J. Biol. Sci. 2013; 20:353-355. doi:10.1016/j.sjbs.2013.03.003.

[10] Jagadeesan G, Sankarsami PS. Hepatoprotective effects of taurine against mercury induced toxicity in rats. J. Environ. Biol. 2007; 28: 753-756.

[11] Amir W, Jahanzaib A, Farhat I, Ashif S, Zahid M, Ghulam M. Pollution status of Pakistan: A retrospective review on heavy metal contamination of water, soil, and vegetables. BioMed. Res. Int. 2014; 2014(2014): 1-29. doi: 10.1155/2014/813206

[12] Olumar B, Ekengele NL, Balla OAD. Évaluation du niveau de pollution par les métaux lourds des lacs Bini et Dang, Région de l'Adamaoua, Cameroun. Afrique Sci. 2014; 10(2):184-198.

[13] Atasie OC, Egbuonu ACC. Quality assessment of waterside River, Ogbor hill, Aba 1: Effect of three-point samples on some hematological parameters of Wistar rats. Int. J. Hydro. 2017; 1(3): 1-5. doi: 10.15406/ijh.2017.01.00013.

[14] Egbuonu ACC, Atasie OC, Oyedemi SO. Quality assessment of Waterside River, Ogbor hill Aba 3: Effect of three-point samples on kidney histo-architecture and some seric bio-functional indicators of Wistar rats. Res. J. Environ. Sci. 2018; 12(1): 14-20. doi: 10.3923/rjes.2018.14.20.

[15] Oloyede OB, Sunmonu TO. Decrease in activities of selected rat liver enzymes following consumption of chemical effluent. J. Appl. Sci. Environ. Manage. 2008; 12(2):95-100.

[16] Alimba CG, Bakare AA, Aina OO. Liver and kidney dysfunction in Wistar rats exposed to municipal landfill leachate. Resources and Environ. 2012; 2(4): 150-163 doi: 10.5923/j.re.20120204.04. 
Quality Assessment of Waterside River, Ogbor Hill Aba 4: Effect of Three-Point Samples on Hepatic Histo-Morphology and Some Seric Bio-Functional Indicators of Wistar Rats

[17] American Public Health Association, APHA. Standard methods of Examination of water and wastewater, 20 ${ }^{\text {th }}$ Eds APHA Washington. 1998; 348-350

[18] Egbuonu ACC, Ogbu AE, Ezeanyika LUS. Dose-related influence of esculetin (6,7-dihydroxy-coumarin) on some liver and prostate function markers of male Wistar rats. J. Biol. Sci. 2012. 12(4): 253-257. doi: 10.3923/jbs.2012.253.257.

[19] Reitman S, Frankel S. Colorimetric method for the determination of serum glutamic oxaloacetic and glutamic pyruvic transaminase. Am. J. Clin. Pathol. 1957; 28: 56-61.

[20] Egbuonu ACC, Obidoa O, Ezeokonkwo CA, Ezaeanyika LUS, Ejikeme PM. Hepatotoxic effects of low dose oral administration of monosodium glutamate in male albino rats. Afr.J. Biotechnol. 2009; 8(13): 3031-3035. doi: 10.5897/AJB09.209.

[21] Egbuonu ACC, Ezeokonkwo CA, Ejikeme PM, Obidoa O, Ezeanyika LUS. Some biochemical effects of sub-acute oral administration of L-arginine on monosodium glutamate fed Wistar albino rats 2: Serum alkaline phosphatase, total acid phosphatase and aspartate aminotransferase activities. Asian J. Bioch. 2010a; 5(2): 89-95. doi: 10.3923/ajb.2010.89.95.

[22] Egbuonu ACC. Effect of some antihypertensives on the serum bilirubin concentration of male Wistar rats. J. Pharm. Pharmacol. Res. 2010; 1(1): 009-012.

[23] Egbuonu ACC, Obidoa O, Ezeokonkwo CA, Ejikeme PM, Ezeanyika LUS. Some biochemical effects of sub-acute oral administration of L-arginine on monosodium glutamate-fed Wistar albino rats 1: Body weight change, serum cholesterol, creatinine and sodium ion concentrations. Toxicol. Environ. Chem. 2010b; 92(7): 1331-1337. doi: 10.1080/02772240903450645.

[24] Egbuonu ACC, Oriji SO. Pulverized Mangifera indica (mango) seed kernel mitigated monosodium glutamate-intoxicated rats' kidney histology and bio-functions. J. Nutri. Health and Fd. Sci. 2017; 5(2): 17. doi: http://dx.doi.org/10.15226/jnhfs.2016.00192.

[25] Egbuonu ACC, Ekwuribe GA. Pulverized Mangifera indica (mango) seed-kernel modulated serum lipid profile in monosodium glutamate-challenged rats. J. Appl. Biotechnol. 2017; 5(2): $72-87$. doi: 10.5296/jab.v5i2.

[26] Egbuonu ACC, Ejike GE. Effect of pulverized Mangifera indica (mango) seed kernel on monosodium glutamate-intoxicated rats' serum antioxidant capacity, brain function and histology. EC Pharmacol. Toxicol. 2017; 4(6): 228-243.

[27] Egbuonu, ACC, Nzewi DC, Egbuonu ONC. Effect of soaking prior to oven-drying on some nutrient and anti-nutrient properties of bitter yam (Dioscorea dumetorum). J. Nutr. Fd. Sci. 2014a; 4(280): 1-4. doi:10.4172/2155-9600.1000280.

[28] Egbuonu ACC, Nzewi DC, Egbuonu ONC. Functional properties of bitter yam (Dioscorea dumetorum) as influenced by soaking prior to oven-drying. Am. J. Fd. Technol. 2014b; 9(2): 97-103. doi:10.3923/ajft.2014.

[29] Smitha PG, Byrappa K, Ramaswamy SN. Physico-chemical characteristics of water samples of Bantwal Taluk, South-western Karnataka, India. J. Environ. Biol. 2007; 289: 591-595.

[30] Fagbohun ED, Lawal OU, Ore ME. The proximate, mineral and phytochemical analysis of the leaves of Ocimum gratissimum L. Int. J. Appl. Biol. and Pharm. Technol. 2012; 3: 15-22.

[31] Farah DP, Hazilawati H, Rosly SM, Shanmugavelu S, Noordin MM. Expression of circulating CD146 associated with endovascular dysfunction in adenine-induced chronic renal failure in rats using an EvaGreen real-time RT-PCR assay. Pertanika J. Tropical Agric. Sci. 2011; 34(2):381-391.

[32] Fahim MA, Nemmar A, Dhanasekaran S, Singh S, Shafiullah YM, Zia S, Hasan MY. Acute cadmium exposure causes systemic and thromboembolic events in mice. Physiol. Res. 2012; 61:73-80.

[33] Jisha JH, Sankar HS, Bhanu VS, Aniladevikunjamma KP, Remya V, Babu P. Cadmium ion induced changes in the protein catabolism of Oreochromis mossambicus. Int. J. Sci. Res. Publications. 2013; 3(8): $1-8$

[34] Bharavi K, Reddy AG, Rao GS, Kumar PR, Kumar DS, Prasadini PP. Prevention of cadmium bioaccumulation by herbal adaptogens. Indian J. Pharmacol. 2011; 43(1): 45-49

[35] Youcef N, Ahlem B, Sakina Z. Amelioration of mercuric chloride toxicity on rat liver with argan oil and sodium selenite supplements. Int. J. Pharma and Bio. Sci. 2013; 4: 839-849.

[36] Diaby V, Yapo AF, Adon AM, Dosso M, Djama AJ. Renal, hepatic and splenic biotoxicity of cadmium sulphate in the Wistar rats . Int. J. Environ. Sci. Toxic. Res. 2016; 4(6): 103-110.

[37] Abdel-Khalek AA. Risk assessment, bioaccumulation of metals and histopathological alterations in Nile tilapia (Oreochromis niloticus) facing degraded aquatic conditions. Bull. Environ. Contam. Toxicol. 2015; 94:77-83. doi:10.1007/s00128-014-1400-9. 
Quality Assessment of Waterside River, Ogbor Hill Aba 4: Effect of Three-Point Samples on Hepatic Histo-Morphology and Some Seric Bio-Functional Indicators of Wistar Rats

[38] Al-Bairuty GA, Shaw BJ, Handy RD, Henry TB. Histopathological effects of waterborne copper nanoparticles and copper sulphate on the organs of rainbow trout (Oncorhynchus mykiss). Aquat. Toxicol. 2013; 126: 104-115. doi:10.1016/j.aquatox.2012.10.005.

[39] Tetreault GR, Bennett CJ, Cheng C, Servos MR, McMaster ME. Reproductive and histopathological effects in wild fish inhabiting an effluent-dominated stream, Wascana Creek, SK, Canada. Aquat. Toxicol. 2012; 110-111: 149-161. doi:10.1016/j.aquatox.2012.01.004.

[40] Egbuonu ACC, Ogbu AE, Ezeanyika LUS. Sub-chronic oral esculetin (6, 7- dihydroxy-coumarin) exposure in male Wistar rats: Effect on some serum functions and organ histology. Asian J. Biochem. 2015; 10(2): 67-77. doi: 10.3923/ajb.2015.

[41] Egbuonu ACC, Ezeanyika LUS, Ejikeme PM, Obidoa O. Histomorphologic alterations in the liver of male Wistar rats treated with 1-arginine glutamate and monosodium glutamate. Res. J. Environ. Toxicol. 2010c; 4(4): 205-213. doi: 10.3923/rjet.2010.205.213.

[42] Jadhav SH, Sarkar SN, Aggarwal M, Tripathi HC. Induction of oxidative stress in erythrocytes of male rats subchronically exposed to a mixture of eight metals found as groundwater contaminants in different parts of India. Arch. Environ. Contam. Toxicol. 2007; 52: 145-151.

[43] Ibegbu AO, Ayuba M, Animoku AA, Daniel B, Sadeeq AA, Peter A, Hamman WO, Umana WE, Musa SA. Effect of ascorbic acid on mercury-induced changes on the liver in adult Wistar rats. IOSR J. Dental and Med. Sci. 2014; 13:10-16. http://dx.doi.org/10.9790/0853-131021016.

[44] Velma V, Tchounwou PB. Chromium-induced biochemical, genotoxic and histopathologic effects in liver and kidney of goldfish, Carassius auratus. Mutat. Res. 2010; 698: 43-51. doi:10.1016/j.mrgentox. 2010.03.014.

Citation: A. C. C. Egbuonu et al., "Quality Assessment of Waterside River, Ogbor Hill Aba 4: Effect of ThreePoint Samples on Hepatic Histo-Morphology and Some Seric Bio-Functional Indicators of Wistar Rats ", International Journal of Research in Environmental Science, vol. 4, no. 1, p. 62-72, 2018. http://dx.doi.org/ 10.20431/2454-9444.0401008

Copyright: (C) 2018 Authors. This is an open-access article distributed under the terms of the Creative Commons Attribution License, which permits unrestricted use, distribution, and reproduction in any medium, provided the original author and source are credited. 